\title{
Activities Using Process-Oriented Guided Inquiry Learning (POGIL) in the Foreign Language Classroom
}

\author{
Catherine Johnson \\ Georgia Southern University
}

\begin{abstract}
Process-Oriented Guided Inquiry Learning, or POGIL, is a method of teaching developed in 1994 and used in college-level math and science courses. The method requires students to work in small groups, view models or diagrams, and answer carefully designed questions that guide them to an understanding of the subject matter on their own, with minimal direction from the instructor. Several studies have proven that POGIL is much more effective than the lecture method upon which math and science instructors have traditionally relied (Hinde and Kovac; Straumanis and Simons; Rajan and Marcus). Although many foreign language instructors no longer use lecture as the primary method of instruction, the application of POGIL, nevertheless, has the potential to prove as beneficial to the language student as it has been for students in the areas of math and science. For example, Frost found that $41 \%$ of 271 chemistry students taught using POGIL earned an A, while $20 \%$ of 285 students taught using a lecture-interactive method earned an A. ${ }^{1}$ This study also found that when POGIL students were given final exams with more difficult questions, they continued to outperform their peers in the lecture-interactive class who had taken final exams with easier questions. Thus, POGIL students not only mastered more content, but also were learning at a higher level than students in the lecture-interactive chemistry course. Another study found that student attrition rates were much lower in POGIL classes $(9.6 \%$ ) compared to traditional classes (21.9\%) (Farrell, Moog, and Spencer 573). Finally, responses on the Stu-
\end{abstract}

\footnotetext{
${ }^{1}$ In the lecture-interactive method, the instructor explained new concepts by a PowerPoint lecture. Students
}

dent Assessment of Learning Gains (SALG) instrument (Carroll, Seymour, and Watson) indicated that students in POGIL classes felt that they had gained a much better understanding of the material than students in the lecture-interactive classes (Frost). Because of its effectiveness, POGIL has gained popularity among instructors at both the high school and college levels primarily in the areas of math and science. These instructors have access to a wealth of POGIL materials designed specifically for their classes. However, because the method has only recently caught the attention of instructors in other fields, there are not many POGIL materials that have been designed for use outside the areas of math and science.

I am one of few foreign language instructors with experience in using the POGIL method. I participated in two POGIL workshops in 2008 and 2009 as well as two POGIL faculty learning communities (2009 and 2010) in which professors in the fields of chemistry, accounting, family and consumer sciences, health and kinesiology, nursing, marketing, and building construction shared specific ideas for the development of materials and the implementation of the method in their classrooms. During the 2008 workshop, which was predominantly attended by faculty in math and science, participants were introduced to the POGIL method with a presentation of the nuclear atom as a model and questions about the model. After the 2008 workshop I modified the nuclear atom worksheet into a model that I could use in my second-semester German class. Working from the basic POGIL

were then given active learning handouts, which engaged them in practicing the concept. 
premise that students learn better when they view a model and work together to answer carefully designed questions about that model, and before I had any empirical evidence of my own that this method worked, I substituted the nuclear atom picture with pictures of people and animals engaged in various activities. I then designed questions meant to guide students to an understanding of how to use the nominative and dative cases. After developing this POGIL activity and grouping students according to strengths, weaknesses, and personal traits such as patience, work ethic, and leadership skills, I implemented it in my second-semester German class. By the end of the class period, it appeared that nearly everyone now understood this grammar point that previously had been so difficult to grasp. The students took their chapter test a few days later. To confirm that they really understood the concept (using the nominative and dative case) which they had studied using POGIL, I made that particular test item somewhat more difficult, requiring students to write complete sentences in which they described various pictures. The class average on that test was $92 \%$. All but two students out of a class of 18 were able to correctly formulate sentences using the grammar concept that they had learned through POGIL. Surprisingly, my weakest student, who had had difficulty since the beginning of the semester with the simplest assignments, composed sentences on the test that were not only all correct, but also used inverted word order.

After observing how one POGIL activity could increase student learning, I attended the second workshop and began writing materials with feedback from my colleagues in the POGIL faculty learning communities. By the beginning of the Fall 2010 semester, I had fully implemented POGIL into my beginning and intermediate German classes. At the end of the Fall 2010 semester, the class average of the 14 students in the second-semester class on the final exam was $92 \%$, and this compared with an average on a nearly identical final exam for the Spring 2010, second-semester class of 16 students of $84 \%$. The 19 students in the Fall 2010 third-semester class averaged $86 \%$ on a more difficult final exam, while the 23 students in the third-semester, Spring 2009 class averaged $85 \%$ on a final exam which provided word banks for the vocabulary and grammar sections. Although there were no word banks on the Fall 2010 final, these students still scored slightly higher.

The above information demonstrates that this method, which originated in the areas of math and science, can be adapted and applied to foreign lan- guage learning with impressive results. POGIL can be successfully used at both the high school and college levels, and I have written and classroom-tested several POGIL activities that can be used at both levels. While I have written activities that promote reading, writing, speaking, and listening skills, as well as activities that teach discrete grammar points and vocabulary, it is not possible to provide individual examples of how to adapt POGIL to all these language skills within the limited scope of this article. Rather, I will explain in more detail what POGIL is, provide general guidelines for writing materials and grouping students, provide two actual classroom-tested activities, and suggest how to make use of student responses, and assess student work.

\section{Getting Started with POGIL}

Before presenting the two activities, it is necessary to briefly outline three of the major characteristics of POGIL. For more detailed information, the reader is encouraged to visit the website («http:// www.pogil.org/about/effectivness») and attend a POGIL workshop. The first and most defining characteristic of the method is that students spend the majority of class time working on activities in small groups with minimal direction from the instructor. If possible, the instructor should attempt to ensure that each group consists of students with varying abilities. The instructor's role is to provide the students with models and questions that guide them to come up with the answers on their own, rather than to tell them the answers. The "Aha, I get it!" moment can be a very exciting and empowering one for students. When they experience this, many are motivated to continue. They can develop confidence in their abilities to learn on their own, develop critical thinking skills, work through language-related frustrations and insecurities, recognize and correct their own mistakes, and learn to work well as part of a team. It is important not to deny students these important experiences by simply providing them the answers, despite the temptation to help if a group is struggling.

The second characteristic of POGIL is that students are assigned specific roles within their groups: the manager, the recorder, and the reflector. In math and science classes, the manager's job is to keep everyone on task, ensure that everyone is participating, and interact with the instructor. The recorder is responsible for recording the names and roles of group members at the beginning of each 
class, as well as turning in a log indicating one item the group understood from the day, and one item the group still has questions on. The recorder is also responsible for turning in group answers. The reflector's job is to comment on group behavior to the manager in an effort to improve the group's effectiveness. The reflector may be called upon to report on group dynamics (to instructor or class). Students stay in their same group for several weeks, or until the first test. However, the instructor assigns students different roles each time the class meets, or when beginning a new activity so that everyone has multiple chances to be the manager, reflector, or recorder.

These roles can be modified to fit the goals of foreign language classrooms. For example, in my class, the manger is called der Leiter. It is the role of the Leiter to make sure that the group is on task and that everyone is participating. The recorder is called der Schreiber and is required to record the group answers on the handouts. A third person is called der Leser and is required to read everything on the handouts to the group members. There may also be fourth person called der Ermutiger. In the group, the role of the Ermutiger is to encourage group members to ask questions if they appear lost or even just a bit confused. Instructors may choose to assign completely different types of roles, or add or subtract roles. What is important is that each student has a specific role that will help the group accomplish the task, thus improving their ability to use the foreign language.

The materials that guide the student are the third major component of POGIL. Writing effective materials with appropriate models and questions is the most difficult and time-consuming aspect of the method. However, once they are written, classroom-tested, and revised for optimal effectiveness, they can be used indefinitely. As more foreign language instructors get involved using POGIL, a larger community of practice will establish itself, in which they will have the opportunity to share their materials, as I am doing. When writing POGIL materials there are five things to keep in mind:

1. Write an objective which describes what the students should be able to do by the end of the class period.

2. Create a model for the students to examine which will help them reach the objective. This model can consist of a dialog, written story, series of pictures, sentences, or any combination of these items. The instructor can also act as a living model, performing and describing in the target language a series of actions for students to consider. The point of the model is to get students to discover patterns that lead them to an understanding of the concept.

3. The instructor should create a series of questions that focuses the students' attention on the model. The instructor should give the students a time limit to answer the questions. Depending on the activity, the time limit can range from 3 to 15 minutes. It is important to formulate questions that guide students, not give them the answers. In a grammar exercise for example, the questions can consist of phrases such as "What differences do you notice when..., Why do you think some verbs..., What rule can you come up with to describe..." etc. Here is an example of a question that is too specific: "If the noun ends in 'in,' do you use 'der' or 'die'?" A better question would be: "Based on the model, how do you know when to use 'der' or 'die'?

4. After the time limit for answering the questions has been reached, students put their knowledge to use in a practical exercise. For example, the instructor can have the groups compose original sentences using the concept they have just learned. At the end of the class period, the instructor collects the materials from the recorder and checks each group's original sentences. If there are errors, the instructor should underline or circle them, but not correct them. The instructor will often find that the group has written a good rule, but did not follow it when writing their sentences. There are also often errors in words that have been copied because students may not have paid attention to detail. Return the papers to the group during the next class period, remind them to look carefully at their rules, the model, and have them correct their errors and return the papers. After working with POGIL materials for a few days, the types of errors described above should decrease significantly.

5. Some instructors are accustomed to conducting their courses entirely (or mostly) in the target language. If this is the case, the instructor will need to consider whether to write the POGIL questions in the target language or in English. At the beginning levels, students are not yet capable of giving opinions or explanations, and thus would not be able to answer a question in the target language beginning with "What rule can you come up with to describe..." However, the instructor can have 
the students answer simple questions and perform simple tasks that draw their attention to the important details in the model. For example, one could provide the following model:

Modell: 1. Ich lerne Deutsch. 2. Heute lerne ich Deutsch. Subsequently, one could provide the following questions:

Fragen: "Wo ist 'ich' in Satz 1? Wo ist 'ich' in Satz 2? Unterstreichen Sie das Wort in Satz 2, das NICHT in Satz 1 ist."

Such questions and tasks would guide students to focus on details and notice how adding certain words to a sentence affect word order. In this case, the goal would be to get students to understand the rule without being asked to articulate it in English. The instructor could then give students an exercise in which they rearrange vocabulary into sentences with correct word order. When writing target-language only materials for beginning levels (as I have done), the models and questions need to be very clear and very systematic.

\section{Activity \#1}

The goal of this activity is to introduce elementary level students to a new grammar concept, the accusative case, using POGIL. This particular activity is designed for use in a beginning level classroom where the target language is used by both instructors and students most or all of the time. The series of questions for this activity can of course be translated for classrooms in which the students are not accustomed to speaking and/or hearing the target language exclusively.

Before introducing the concept, students should already be familiar with the differences between masculine, feminine, and neuter nouns in the nominative case. They should also possess an understanding of basic verb conjugation. Before class, decide who is going to be in what group of three or four. Try to form groups so that there is a student with strong, average and weak language skills in each group. Decide who will be the manager or der Leiter. When using POGIL for the first time, the instructor should try to choose managers who seem to possess some leadership skills and who seem to have strong language skills. When the roles are changed for the next class meeting, everyone will have had at least one opportunity to get some idea of what a good manager does. Next decide who will be the recorder or der Schreiber. If possible, choose the student with the weakest language skills for this role. If the student does not understand what to write, it will be necessary to ask for clarification. The reader or der Leser can be a student with average language skills. The Leser should read everything on the handouts to the other group members. If there is a fourth person, this student can take on the role of the encourager or der Ermutiger, whose job it will be to ensure that everyone understands the concepts, by periodically asking questions such as Versteht ihr?, Was ist nicht klar? Ich glaube, ich verstehe das nicht. Warum schreibt man das? and so forth.

As soon as it is time for class to begin, the instructor should put students into groups, and explain the roles to which they have been assigned. Be sure the students' desks are turned toward each other to ensure better communication and interaction. Next the instructor should give the Schreiber in each group Handout \#1 which contains the illustrations in the Appendix. The instructor then should write the sentence on the board that describes what is happening in each picture, as the Schreiber in each group copies the sentence onto the handout underneath the corresponding picture. The instructor controls the pace as all students concentrate on each picture and sentence. The instructor should be sure to go slowly, and read the sentence aloud as she writes it, especially emphasizing the articles den and der. These illustrations and sentences comprise the model that will lead students to begin to understand the concept. Some students will be very eager to ask questions or express non-comprehension before the instructor is finished writing. However, it is important not to answer their questions since a critical component of the POGIL method demands that instructors not give students the answers.

Instead, the instructor should encourage students to be patient and to continue looking at the pictures and the following sentences as they are written one by one. The instructor writes the following sentences exactly as they are, keeping the word order as is:

1. Der Mann hält den Hund.

2. Den Mann hält der Hund.

3. Den Jungen tritt die Katze.

4. Der Junge tritt die Katze.

5. Die Frau kauft den Kühlschrank.

6. Die Frau kauft der Kühlschrank.

7. Das Hundefutter frisst der Hund.

8. Das Hundefutter frisst den Hund. 
9. Die Maus hält den Elefanten.

10. Die Maus hält der Elefant.

11. Die Blume hält das Mädchen.

12. Das Mädchen hält die Blume.

13. Der Mann küsst die Frau.

14. Den Mann küsst die Frau.

After all fourteen sentences have been copied, give the Schreiber in each group Handout \#2 (see Appendix). The questions on Handout \#2 are designed to focus students' attention on important details and patterns which will guide them to an understanding of the accusative case on their own with minimal help from the instructor. Remind students what their roles are, and have the Schreiber write the group member names on the handout corresponding to Leiter, Leser, and Schreiber. Give the students 12-15 minutes to answer the questions. Circulate among the groups, listen to them talk and think it through, and look at what they are writing. If students ask the instructor if something is right or wrong, the instructor should direct the student to ask group members what they think. Again, it is important to resist the temptation to give students the answers, even if they appear to be headed in the wrong direction. If given time, one of the group members will usually see the error and get the group back on the right track. It has been my experience that all groups were able to correctly answer all questions on the handout and recognize a pattern that shows them when to use der, den, die or das.

After the 12-15 minutes have passed, give the Schreiber in each group a different set of 6-8 pictures showing people and/or animals engaged in various activities. On the same handout provide the students with a list of nouns and verbs, but no articles. For example: "Mädchen (n), Jungen(m), Mutter(f), Kuchen(m), isst, küsst, trinkt ..." Give the students an additional 4-6 minutes to write complete sentences that describe this new series of 6-8 pictures. Remind them to look at Handouts \#1 and \#2 and use the questions and their answers to guide them to write accurate descriptions of the pictures. These sentences will tell the instructor how well students are able to use the concept in a practical application.

If the students are accustomed to using some English in the classroom (as mine were in the Spring of 2010), they may discuss the following questions in their groups. (1) What rule can you come up with to describe when to use der and when to use den? (2) How do you know when to use die or das? (3) How can Germans understand what is meant if there are two feminine words, two neuter words or a combination of feminine and neuter words in a sentence? (4) How do the rules for word order differ in German and in English? After the students have had a few minutes to discuss these questions in their groups, the instructor can ask each Leiter to share their answers with the class. The instructor will find that students have different ways of articulating the same rule. For example, in my class, one group said, "You use 'der' for the subject of the sentence and 'den' for the direct object." Another group said, "If somebody's doing something you use 'der,' but if they're being affected you use 'den." Another said, "The same thing they said, but 'der' and 'den' are just for the masculine words." Articulating the same rule in several different ways is good, because there are many different ways of understanding a concept. The way the textbook or the instructor explains a concept often does not match the way a student thinks, especially if the student does not possess a good understanding of grammar and the terminology. It has been my experience that students do learn to consistently produce grammatically correct language to accurately convey meaning without being able to articulate the formal linguistic functions that describe their language production. If the main goal of one's foreign language program is to teach students to express themselves both accurately and meaningfully, the program will have succeeded in reaching its primary goal. The instructor should remember that one of POGIL's main features is to let the model and the questions guide students through the process of learning the language as they discover patterns and develop their own explanations. In contrast to rote memorization of charts, the POGIL method has the benefit of requiring that students use the language to express ideas and content, even at the most basic of levels.

After all groups have finished writing their sentences and/or discussing their responses, the instructor can have the Schreiber indicate on the handout how well the individual group members understand the concept by circling the appropriate descriptors in the following sentence: Ich verstehe diese Aktivität sehr gut, gut, ein bisschen, oder gar nicht. The Schreiber should write down one or two items that are not clear if anyone in the group indicates that they understand the concept ein bisschen or gar nicht. Finally, the instructor should collect all the handouts. 


\section{Making Use of Student Responses}

The responses on the group handouts can be used for various purposes. Most importantly, the instructor can use them to assess how well the groups understand a concept and how accurately they are able to apply this understanding in practice. Sometimes a group will have answered all questions correctly and indicated that all members understand the concept sehr gut. However, in the practical application several of their sentences will be incorrect. This usually occurs because students failed to refer to the model, their answers to the questions, and/or their own rule while writing their sentences. Errors also frequently occur because students do not read or follow the directions on the handout. When mistakes occur, circle or underline the incorrect word or sentence, indicate that the group should revisit the model, and/or read the directions, but do not explain why a word or sentence is wrong, and do not subtract points. During the next class period, the instructor should return the handouts and give the groups 3-5 minutes to discuss the errors, discover the reasons for the mistakes, and correct them. Students should return the handouts to the instructor, who can check them after class to assess how well the groups remedied their errors.

The handouts can also be used for grading purposes. If the instructor gives students a grade for class participation, the group could be graded based upon how much of the handout they completed. For another example, after students have worked on a POGIL activity in groups, they could be given a similar activity as an individual quiz during the next class period, especially if everyone rated their understanding of the concept at gut or sehr gut. In addition to giving the students an individual grade for this quiz, the instructor can also award extra credit points to groups who average above $90 \%$. Groups are not penalized for scoring below $90 \%$. The instructor could also simply verbally praise the group with the highest quiz average, emphasizing the importance of working together to ensure that everyone understands the activity. If one group has a significantly low average because one person really did not understand the concept, the other members will be more motivated to help that person so that the group will do better on the next quiz. It has been my experience that this type of cooperative competition fosters better group interaction and ensures that the weakest students do not fall far behind.

\section{Activity \#2}

This short activity uses POGIL to give students practice in guessing meaning from context without English translations. Students can practice this important language skill at the beginning of each class period as a fun warm-up activity. After students have gotten into their groups, the instructor can write one interesting word, saying, riddle, or joke in German on the board. Some examples that I have used are: das Stinktier, die Glühbirne, an die Decke gehen, Was hat zwei Köpfe, zwei Arme, und sechs Beine? Was sagt ein Hund, wenn er auf Sandpapier sitzt? and die Massenvernichtungswaffen. Students at all levels, from true beginners to advanced, have been able to guess these meanings by thinking both creatively and concretely. What follows is one example of how to guide students to an understanding of a very long word using POGIL.

I have given students in the first few weeks of introductory German die Massenvernichtungswaffen to consider. The first reaction is amazement. They initially believe they will never figure out what it means without looking in a dictionary. Tell students that the word is the model and that the Schreiber should write it down. Guide their thinking process by asking the groups, Wie viele kleine Wörter sehen Sie in dem großen Wort? Give the groups a few seconds to consider how many words they see. Some students who enjoy watching war movies will notice the word Waffen. Some will see the word nicht, while others will see Massen. Ask each Leiter how many smaller words their group identified. Next ask them Was sind die kleinen Wörter? Write them on the board. The instructor should then complete the model by writing examples of meaning in German for each word part. For example, Massen=viele Personen, vernichten= kaputt machen, Waffe = eine Bombe oder eine Pistole. Give the groups about a minute to discuss what they think the word means in English. Encourage them to think both creatively and concretely. Have the Schreiber write down the group's English translation on a small scrap of paper. Collect the papers and read the guesses. Some groups will come up with interestingly incorrect, but creative answers, such as "a lot of incompetent people who break weapons." Other groups will get the answer "weapons of mass destruction," and be very proud of themselves for correctly discerned the meaning of such a long and complex compound word. Those who did not get the answer will nevertheless experience the enthusiasm that accompanies a moment of clarity 
when they recognize the connections that lead to comprehension.

The ability to make such connections is a critical component of all four language skills. For example, a reading activity using POGIL would employ a text in the target language as the model, along with definitions of unfamiliar vocabulary also in the target language. Working together, students would first guess the English equivalents of the unfamiliar vocabulary by looking at word parts as well as the definition. Then they would demonstrate an understanding of the text by answering detailed questions that begin with "where", "when" and "what", and gradually progress to the more difficult "why" and "how" questions. Listening comprehension activities using POGIL would employ a dialog in the target language as a model, along with definitions of a few unfamiliar words, also in the target language. The job of the Schreiber in the group would be to write down what each person in the group heard and/or understood. Working with their collected notes, the group would then demonstrate to what degree they understood the dialog through a written summary and/or by answering questions, which the instructor verbally provides. A writing activity using POGIL would require students to read a short dialog in which a particular word, phrase or idiom is used. Students would then work together to write their own short dialogs using instructor-provided lists of new words, phrases and/or idioms. A speaking activity would involve one student in the group (der Leser) interviewing the second student (der Sprecher), while the third student (der Schreiber) rates the Sprecher on how well she responded to the questions using instructor-provided guidelines.

\section{Conclusion}

The POGIL method is in many ways perfectly suited to teaching foreign language to students at the high school and university levels. The method requires students to work in groups, which can foster the development of communicative skills, especially in classrooms where students are expected to use the target language most or all of the time. POGIL teaches students to analyze models and look for patterns, which can help them discover, recognize and understand the patterns in the gram- matical structures of the target language. The method gives students the opportunity to practice problem solving and critical thinking skills, which are key components in developing the ability to guess meaning from context. In short, not only does the POGIL method have the potential to prepare students to become proficient in the target language, it may also prepare them to function in real world settings, both at home and abroad. Most employers are looking for people who can work as a team, think critically, analyze and solve problems, pay attention to details, recognize and correct mistakes, and accomplish tasks with little supervision, and POGIL addresses all of the above.

Although I have conducted no long-term experimental studies on the effectiveness of POGIL in my foreign language classrooms, the preliminary results of student performance after one semester of using POGIL appear promising.

\section{References}

Carroll, Stephen, Elaine Seymour, and Tim Watson. "Student Assessment of Learning Gains (SALG)." 2007. «http://www.salgsite.org».

"Effectiveness of POGIL." The POGIL Project. 4 May 2011. «http://www.pogil.org/about/ effectiveness».

Farrell, John J., Richard S. Moog, and James N. Spencer. "A Guided Inquiry General Chemistry Course." Journal of Chemical Education 76.4 (1999): 570-74.

Frost, Laura DeLong. "Creating a Relevant Learner-Centered Classroom for Allied Health." Making Chemistry Relevant: Strategies for Including All Students in a Learner-sensitive Classroom Environment. Ed. Sharmistha Basu-Dutt. Hoboken, NJ: John Wiley \& Sons, 2010. 127-44.

Hanson, David, and Troy Wolfskill. "Process Workshops - A New Model for Instruction." Journal of Chemical Education 77.1 (2000): 120-30.

Hinde, Robert J., and Jeffrey Kovac. "Student Active Learning in Physical Chemistry." Journal of Chemical Education 78.1 (2001): 93-99.

Rajan, Nithya, and Leanne Marcus. "Student Attitudes and Learning Outcomes from Process Oriented Guided-Inquiry Learning (POGIL) Strategy in an Introductory Chemistry Course for Non-Science Majors: An Action Research Study." The Chemical Educator 14.2 (2009): 85-93.

Straumanis, Andrei, Emily A. Simons. "A Multi-Institutional Assessment of the Use of POGIL in Organic Chemistry." ACS Symposium Series 994 (2008): 226-239. 
Appendix. Modell: Handout \#1
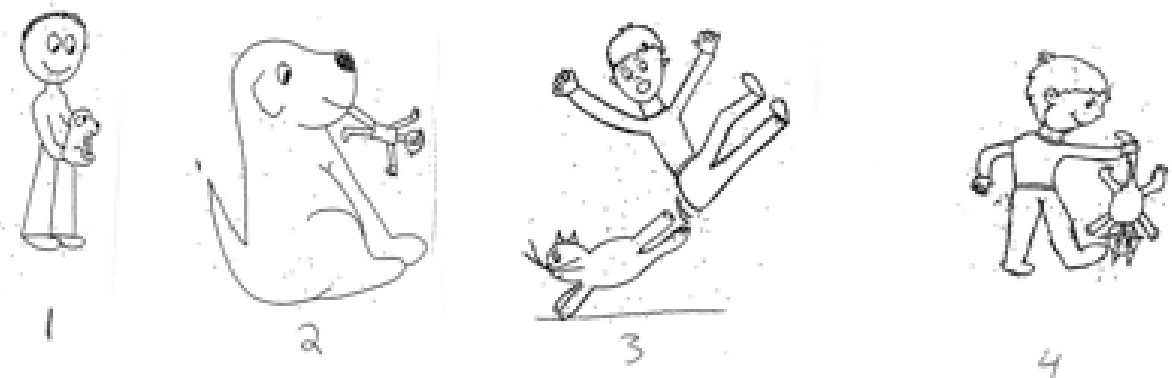
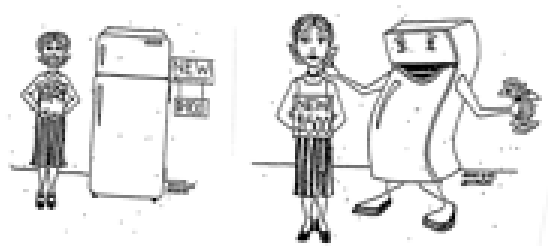

6

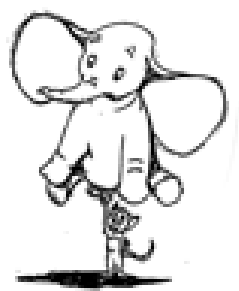

9

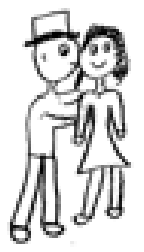

13
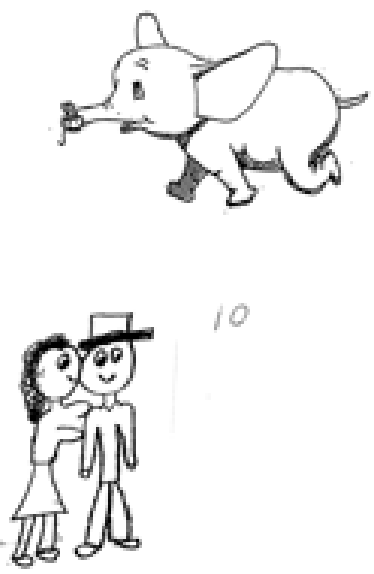

14

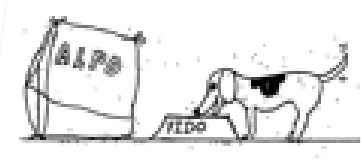

7

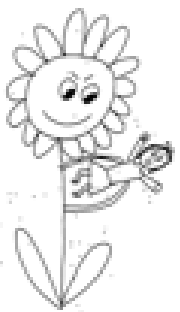

II

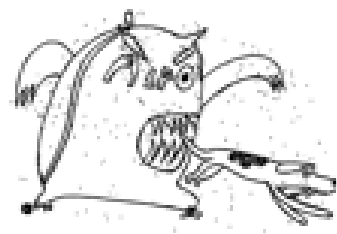

8

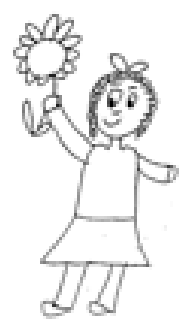

12 


\section{Handout \#2}

Aktivität \#1

Leiter

Leser

Schreiber

\begin{tabular}{||c|c|c||}
\hline Maskulin Wörter & Feminin Wörter & Neutral Wörter \\
\hline der Mann & die Katze & das Hundefutter \\
\hline der Hund & die Frau Mädchen \\
\hline der Junge & die Maus & \\
\hline der Kühlschrank & die Blume & \\
\hline der Elefant & & \\
\hline
\end{tabular}

1. Schauen wir Bild \#1 an. Ist "Hund" maskulin, feminin, oder neutral?

2. Ist "Mann" maskulin, feminin, oder neutral?

3. Schreibt man der, den, die oder das für "Mann" in Bild \#1?

4. Schreibt man der, den, die oder das für "Hund" in Bild \#1?

5. Wer/Was macht etwas in Bild \#1?

6. Schauen wir Bild \#2 an. Schreibt man der, den, die oder das für "Mann" in Bild \#2?

7. Schreibt man der, den, die oder das für "Hund" in Bild \#2?

8. Wer/Was macht etwas in Bild \#2?

9. Schauen wir Bild \#3 an. Ist "Junge" maskulin, feminin, oder neutral?
10. Ist "Katze" maskulin, feminin, oder neutral?

11. Schreibt man der, den, die oder das für "Jungen" in Bild \#3?

12. Schreibt man der, den, die oder das für "Katze" in Bild \#3?

13. Wer/Was macht etwas in Bild \#3?

14. Schauen wir Bild \#4 an.

15. Schreibt man der, den, die oder das für "Junge" in Bild \#4?

16. Schreibt man der, den, die oder das für "Katze" in Bild \#4?

17. Wer/Was macht etwas in Bild \#4?

Follow this pattern of questioning for pictures 5 through 14. 